\title{
Mechanical properties of rough and dehulled rice during drying
}

\author{
Osvaldo Resende ${ }^{\mathrm{a}}$, Paulo César Corrêa ${ }^{\mathrm{b}}$, Gabriel Henrique Horta de \\ Oliveira $^{c^{*}}$, André Luis Duarte Goneli ${ }^{\mathrm{d}}$, And Carmen Jarén ${ }^{\mathrm{e}}$ \\ a Instituto Federal Goiano, Agronomy Department, Rio Verde-GO, Brazil \\ ${ }^{\mathrm{b}}$ Universidade Federal de Viçosa, Department of Agricultural Engineering, Viçosa-MG, Brazil \\ ${ }^{\mathrm{c}}$ Instituto Federal de Brasília, Campus Gama, Brasília-DF, Brazil \\ ${ }^{d}$ Universidade Federal da Grande Dourados, Department of Agricultural Engineering, Dourados-MS, Brazil \\ ${ }^{\text {e }}$ Public University of Navarre, Department of Project and Rural Engineering, Valencia, Spain \\ ${ }^{*}$ Corresponding author \\ gabriel.oliveira@ifb.edu.br \\ TEL: +55-61-21032259
}

Received: 24 July 2012; Published online: 18 October 2013

\begin{abstract}
This work aimed to determine the mechanical properties of rough and dehulled rice grains, for different moisture contents, by obtaining their rupture force, deformation, maximum compression force and proportional deformity modulus under a compression test. Rice grains, with moisture content varying from 0.12 to 0.30 (d.b.), were subject to an uniaxial compression in order to analyze these properties. On reducting moisture content the rupture force increased from 37.2 to $70.6 \mathrm{~N}$ for dehulled rice and 48.0 to $79.5 \mathrm{~N}$ for rough rice. The average compression force varied from 131 to $171 \mathrm{~N}$ for dehulled rice and 203 to $283 \mathrm{~N}$ for rough rice. The value range of proportional deformity modulus was from $5.5 \times 109$ to $7.4 \times 10^{9} \mathrm{~Pa}$ for dehulled rice and $9.5 \times 10^{9}$ to $12.3 \times 10^{9} \mathrm{~Pa}$ for rough rice. Rough rice presented more resistance to compression compared to dehulled rice.
\end{abstract}

Keywords: proportional deformity modulus; rupture force; Oriza sativa L.; compression

\section{Introduction}

Determination of the mechanical properties of agricultural products is necessary for the design of equipment and to achieve maximum efficiency without compromising the final quality of the product (Corrêa, da Silva, Jaren, Afonso Junior, \& Arana, 2007). Grain cracking and breakage occur when subject to forces which exceed the material's mechanical strength (Liu, Haghighi, Stroshine, \& Ting, 1990).

During harvesting, handling, transportation and storage operations grains are submitted to a series of static pressures, of different magnitude, and dynamic pressures. Impacts may occur causing bruising, crushing and cracking due to high velocity. These impacts increase grain susceptibility to deterioration during storage (Goneli, Correa, Resende, \& Reis Neto, 2007; Bargale, Irudayaraj, \& Marquis, 1995). According to Guha and Ali (2006), temperature control features, such as gelatinization (as well as moisture content), molecular degradation and/or reassociation during processing also govern the final textural and functional properties of the product.

Rice grains are subject to major quality loss during common processing. The most critical and delicate operation is dehulling where the hulls are extracted from the rough rice (Corrêa et al., 2007). The mechanical forces applied to the rough rice during the dehulling operation 
break the grains. The extent and type of damage depends on the variety and physical characteristics of both rough and dehulled rice, as well as the applied force which is one of the most important factors for cracking rice.

Knowledge of fracture characteristics of both grains under compressive loading becomes imperative for the design of an efficient dehulling system as well as the optimization of process and product parameters (Gupta \& Das, 2000). Kunze and Choudhury (1972) conducted storage tests with rice under different relative humidity, concluding that higher values of moisture content lead to lower fissuring of rice. Dong, Lu, Liu, Koide, and Cao (2010) analyzed the effects of drying and tempering on rice fissuring. These authors stated that the percentage of fissured kernels increased with increasing drying time and decreasing tempering time. Even though information on rice fracture characteristics is available, further knowledge about the rough rice and dehulled rice is required due to different cultivars and environmental conditions.

Within several mechanical properties, the deformity modulus permits comparison to be made between the relative resistances within different materials. When determining the deformity modulus of a product, it is necessary to separate the total deformation into two components: elastic and plastic. Afterwards, with force curves as a function of the deformation during the application of a load on the product, assuming the total deformation, the deformity modulus can be obtained. Couto, Batista, and Devilla (2002), studying the mechanical behavior of coffee berries, concluded that the deformity modulus is considered more significant than the elasticity when a product is compressed; thus, the total deformation has more practical application.

The deformity modulus is a function of the Poisson's ratio and it is assumed to be a constant value for each material. As it is unknown for rice, another variable proportional to the deformity modulus, called the proportional deformity modulus, can be used (Batista, Couto, Cecon, \& Peixoto, 2003).

Several factors affect the mechanical properties of the agricultural products, with drying temperature, product moisture content, the type of force and where the force is applied as the most important and frequently studied parameters (Mohsenin, 1986; Prussia \& Campbell, 1985; Li, Zhang, Puri, \& Manbeck, 1989; Zhang, Li, Puri, \& Manbeck, 1989).

On determining the proportional deformity modulus of coffee fruits at different ripening stages (green, greenish and cherry) and different moisture content, Couto et al. (2002) concluded that the proportional deformity modulus decreases as the fruit deformation increases.

Several researchers state that the drying air temperature is the most influential factor affecting the mechanical properties of agricultural grains (Gustafson \& Hall, 1972; White, Ross, \& Poneleit, 1982).

Batista et al. (2003) observed that the proportional deformity modulus of coffee fruits, in the moisture content range of 0.14 to 1.50 (d.b.), at three ripening stages, under different drying temperatures $\left(40,50\right.$ and $\left.60^{\circ} \mathrm{C}\right)$ decreases with product deformation. The proportional deformity modulus values varied between $2.0 \mathrm{x}$ $10^{7}$ to $18.0 \times 10^{7} \mathrm{~Pa}$ for the cherry coffee fruits, $5.0 \times 10^{7}$ to $40.0 \times 10^{7} \mathrm{~Pa}$ for green coffee fruits and $1.0 \times 10^{7}$ to $50 \times 10^{7} \mathrm{~Pa}$ for greenish coffee fruits.

Liu et al. (1990) verified through a compression test, the significant effects of moisture content and drying air temperature on the mechanical behavior of soybeans. Reducing the drying air temperature increases the rupture force, whilst increasing the moisture content decreases the rupture force.

Gupta and Das (2000), whilst evaluating the mechanical behavior of sunflower seeds, observed that increasing the moisture content of the product from 3.8 to $16.6 \%$ w.b. reduces the rupture force and increases its deformation.

Henry, Su, and Zhang (2000), whilst studying the resistance of soybeans to compression, on three different orientations, observed that the rupture force, normal to the cotyledons' divisions, was higher than the other orientations and presented lowest deformation. Also, the resistance to compression decreases as moisture content increases.

Oliveros-Tascón, Montoya-Restrepo, and Ayala (2002) evaluated the influence of coffee berry borer attack on the firmness of cherry coffee fruit 
and parchment coffee (dried and wet) which were subjected to a compression test. For the cherry coffee fruits, no significant difference between the normal and coffee borer fruit firmness was observed, but for the parchment coffee the grain firmness was statistically superior to grains with borer. This is evidence of the influence of the insect attack on the mechanical properties of the coffee fruits.

The objectives of this work were to determine and compare the mechanical properties of rough and dehulled rice (cv. Urucuia) at different moisture content in order to obtain the rupture force, deformation on rupture, maximum compression force and proportional deformity modulus of the product when subjected to a compression test, at the natural rest position, for a fixed deformation of $0.001 \mathrm{~m}$.

\section{Materials and Methods}

Rough rice grains (cv. Urucuia), thin and long type, were harvested with a moisture content of approximately 0.30 (d.b.). This cultivar was chosen due to its recommendation for Minas Gerais state, Brazil and lack of data for local producers. Different levels of moisture content were obtained by drying grains in the oven, with forced air circulation, at a temperature of $40{ }^{\circ} \mathrm{C}$ and relative humidity of $25 \%$. The moisture content reduction along the drying process was observed by a gravimetric method (mass loss) using a semianalytical scale with $0.01 \mathrm{~g}$ of precision. The product was dried until a final moisture content of 0.12 (d.b.) was achieved.

The moisture content was determined using the oven method at $105 \pm 1{ }^{\circ} \mathrm{C}$ until constant mass in three consecutive measurements. For every moisture content level, samples were homogenized and divided into two portions: the first one as rough rice, and the second one as dehulled rice, taking out the hulls manually. Afterwards the product was used to determine the mechanical properties at a controlled temperature of 22 $\pm 2{ }^{\circ} \mathrm{C}$.

The grain compression tests were performed for each grain individually in the universal testing machine, model TA.HD Texture Analyser, using a load cell of $500 \mathrm{~N}$.

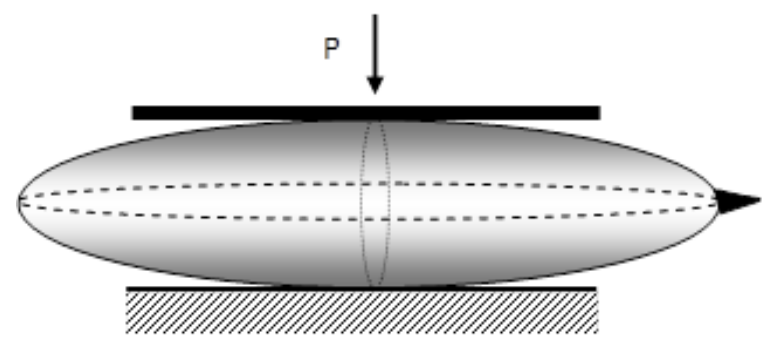

Figure 1: Rice grain orientation during the compression test at its natural rest position.

Tests were performed prior to the research in order to ascertain the velocity and deformation parameters. The grains, at their natural rest position (Figure 1), were subjected to uniaxial compression, between two rigid parallel plates, by applying the force at a velocity of $0.001 \mathrm{~m} \mathrm{~s}^{-1}$, with eleven repetitions for rough and dehulled rice. The compression test was stopped when the deformation achieved $0.001 \mathrm{~m}$.

Using the curves of force versus rice grain deformation obtained after the tests, the force and the deformation values in rupture were used to determine the bioyield point. This point is defined as the position on the curve where increasing deformation is associated with decreasing compression force (ASAE. 1974), indicating that rupture has started and structure disorganization of the product is occuring.

The proportional deformity modulus of rice was determined for a deformation of $0.001 \mathrm{~m}$, adapted from deformations used by Batista et al. (2003) in accordance to the following expression:

$$
E_{p}=\frac{E}{\left(1-\mu^{2}\right)}=\frac{0.531 F}{D^{3 / 2}}\left[2\left(\frac{1}{r}+\frac{1}{R}\right)^{1 / 3}\right]^{3 / 2}
$$

in which,

$E p=$ Proportional deformity modulus, Pa;

$E=$ Deformity modulus, Pa;

$F=$ Force, $\mathrm{N}$;

$D=$ Total deformation (elastic and plastic) of the body on the upper and downer plate contact points, m;

$\mu=$ Poisson's ratio, dimensionless;

$R, r=$ Radius of Curvature of the contact point,

IJFS | MONTH 2013 Volume 2 |pages 158-166 
$\mathrm{m}$.

The radius of curvature ( $r$ and $R$ ) values of the grain were obtained at the contact points, for each moisture content, by adjusting the curvatures of the grain body to the circumferences according to coordinate planes of the compression position, as illustrated in Figure 2 . The radius of curvature values " $r$ " and " $R$ " are the radius of the grain and the radius of a circumscript circle that contains the grain.

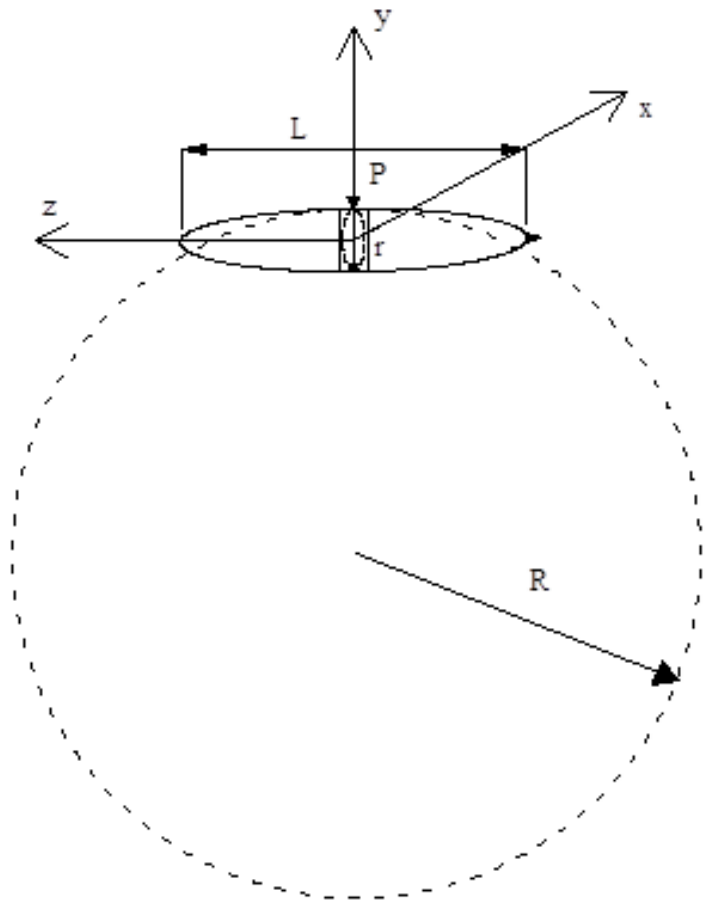

Figure 2: Radius of curvature of the rice grain in the contact region between the product and compression plate during the compression test.

The rupture force, deformation in rupture, maximum compression force and proportional deformity modulus data were analyzed as a function of moisture content and the two types of processing (rough and dehulled).

The experiment was performed according to a statistical factorial scheme 7 by 2 , with seven levels of moisture content and two types of processing, on an entirely randomized design with eleven replicates for each type of rice and moisture content.

For qualitative factors, the means were compared by applying the Tukey's test, at probability level of $5 \%$. The quantitative factors were subjected to regression analysis in order to establish the equations representing the interactions between the analyzed variables. The choice of models was based on the significance of the regression coefficients by the Student t-test, adopting the probability level of $5 \%$ and the determination coefficient $\left(\mathrm{r}^{2}\right)$.

\section{Results and Discussion}

The average radius of curvature values of rough and dehulled rice grains, at different moisture contents, which were used to determine the proportional deformity modulus are shown in Table 1.

Table 1: Average radius of curvature values for rough and dehulled rice grains $\left(\mathrm{x} 10^{-3} \mathrm{~m}\right)$ at different moisture contents during the drying process.

\begin{tabular}{|c|c|c|c|c|}
\hline \multirow{3}{*}{$\begin{array}{c}\text { Moisture } \\
\text { content (d.b.) }\end{array}$} & \multicolumn{4}{|c|}{ Position } \\
\hline & \multicolumn{2}{|c|}{ Rough rice } & \multicolumn{2}{|c|}{ Dehulled rice } \\
\hline & $\mathrm{r}$ & $\mathrm{R}$ & $\mathrm{r}$ & $\mathrm{R}$ \\
\hline 0.127 & 1.48 & 9.42 & 1.40 & 8.55 \\
\hline 0.155 & 1.46 & 9.45 & 1.38 & 8.53 \\
\hline 0.176 & 1.46 & 9.41 & 1.37 & 8.56 \\
\hline 0.190 & 1.49 & 9.38 & 1.38 & 8.49 \\
\hline 0.220 & 1.49 & 9.43 & 1.41 & 8.54 \\
\hline 0.258 & 1.39 & 9.40 & 1.35 & 8.50 \\
\hline 0.296 & 1.36 & 9.38 & 1.32 & 8.52 \\
\hline
\end{tabular}

As observed in Table 1 the radius of curvature values varied with moisture content, although with no clear trend as a function of this variable. The radius of curvature values were higher for rough rice than dehulled rice.

The analysis of variance results, for different experimental tests, on the rupture force, deformation in rupture, maximum compression force and the proportional deformity modulus of rough and dehulled rice are shown in Table 3. Processing type and moisture content independently had a significant effect on the rupture force, deformation in rupture, maximum compression force and proportional deformity modulus of the rice

\begin{tabular}{l|l|l|l} 
IJFS & MONTH 2013 Volume 2 & pages 158-166
\end{tabular} 
Table 2: Analysis of variance on rupture force $\left(\mathrm{F}_{r}\right)$, deformation in rupture $(\varepsilon)$, maximum compression force $\left(\mathrm{f}_{m}\right)$ and proportional deformity modulus $\left(\mathrm{E}_{p}\right)$ for rough and dehulled rice as a function of moisture content

\begin{tabular}{rccccc}
\hline \multirow{2}{*}{ Source of Variation } & \multirow{2}{*}{ D.F. } & \multicolumn{5}{c}{ Mean square } \\
\cline { 3 - 6 } & $\mathrm{F}_{r}(\mathrm{~N})$ & $\varepsilon\left(\mathrm{x} 10^{-3} \mathrm{~m}\right)$ & $\mathrm{F}_{m}(\mathrm{~N})$ & $\mathrm{E}_{p}\left(\mathrm{x} 10^{18} \mathrm{~Pa}\right)$ \\
\hline Processing (B) & 1 & $7105.31^{* *}$ & $0.3233^{* *}$ & $236647.26^{* *}$ & $504.98^{* *}$ \\
Moisture content (U) & 6 & $3285.66^{* *}$ & $0.0032^{*}$ & $7240.89^{*}$ & $13.82^{*}$ \\
B x U & 6 & $85.53^{\text {ns }}$ & $0.0014^{n s}$ & $2550.25^{\text {ns }}$ & $4.75^{\text {ns }}$ \\
Residue & 140 & & & & \\
\hline Total & 153 & & & \\
\hline
\end{tabular}

*Significant at $5 \%$ probability by $\mathrm{F}$ test;

** Significant at $1 \%$ probability by $\mathrm{F}$ test;

${ }^{n s}$ Non significant.

grains.

The mean rupture forces of rough and dehulled rice as a function of moisture content (d.b.) are shown in Figure 3. The rupture forces were found to be significantly higher for rough rice than dehulled rice, for most of the moisture contents, according to the Tukey's test at $5 \%$ probability. Reducing the moisture content from 0.30 to 0.12 (d.b.) resulted in the force necessary to achieve the bioyield point increasing from 48.0 to 79.5 $\mathrm{N}$ for rough rice and 37.2 to $70.6 \mathrm{~N}$ for dehulled rice.

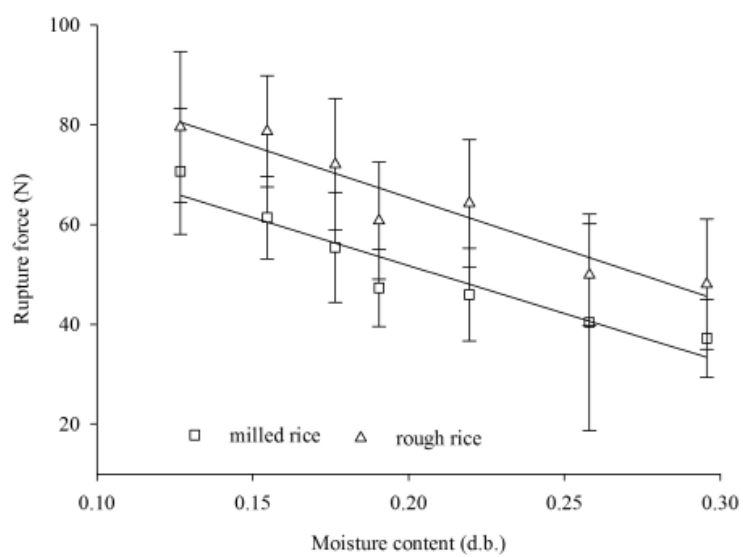

Figure 3: Mean rupture force $(\mathrm{N})$ values of rough and milled rice as a function of moisture content (d.b.). Mean values followed by the same letter for the same moisture content do not differ according to the Tukey's test at $5 \%$ probability.
The force necessary to rupture the rice grain increased with moisture content reduction, which agrees with the results obtained by different researchers working with different agricultural products (Laskowski \& Lysiak, 1999; Vursavus \& Ozguven, 2004; Altuntas \& Yildiz, 2007). The rupture force for rice grains is extremely dependent on its moisture content within the range of this experiment $(0.30$ to 0.12 d.b.). The rupture force variation as a function of its moisture content for rough and dehulled rice can be represented adequately according to the following expressions:

$$
\begin{array}{ll}
\hat{F}_{r r}=106.7-206.7^{\Leftrightarrow} X & r^{2}=0.91 \\
\hat{F}_{m r}=90.2-192.2^{\Leftrightarrow} X & r^{2}=0.90
\end{array}
$$

in which:

$F_{r} r=$ Rupture force of rough rice, $(\mathrm{N})$;

$F_{m} r=$ Rupture force of dehulled rice, (N);

$X=$ Moisture content, (d.b.).

**Significant at $1 \%$ probability, through the $\mathrm{t}$ test.

The rupture force increased by approximately 2.1 $\mathrm{N}$ for rough rice and $1.9 \mathrm{~N}$ for dehulled rice as the moisture content was reduced to 0.01 (d.b.). A simple linear equation represents adequately the experimental data.

The mean deformation in rupture values of rough and dehulled rice for different moisture contents are shown in Figure 4. The deformation in rupture was significantly superior in the rough rice for all moisture contents. This is expected as the presence of hulls in rough rice provides higher 


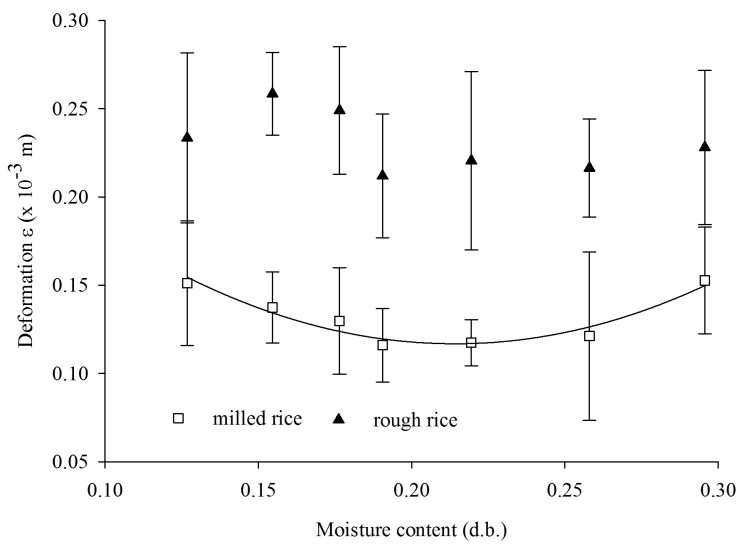

Figure 4: Mean deformation values (x $10^{-3} \mathrm{~m}$ ) in rupture of rough and milled rice at different moisture contents. Mean values followed by the same letter for the same moisture content do not differ according to the Tukey's test at $5 \%$ probability.

mechanical resistance, and thus requires higher deformation to rupture the grains. For the moisture content range of 0.30 to 0.12 (d.b.) during the compression test, the deformation in rupture varied from 0.21 to $0.26 \times 10^{-3} \mathrm{~m}$ for rough rice and 0.12 to $0.15 \times 10^{-3} \mathrm{~m}$ for dehulled rice. The variation of the deformation in rupture as a function of moisture content for dehulled rice can be described adequately according to the following expression:

$$
\hat{\varepsilon}=0.34-2.12^{* *} X+4.95^{* *} X^{2} \quad r^{2}=0.92
$$

in which:

$\varepsilon=$ Deformation in rupture, $\left(\mathrm{x} 10^{-3} \mathrm{~m}\right)$;

** Significant at $1 \%$ probability, through the $\mathrm{t}$ test.

Similar behavior was observed by Vursavus and Ozguven (2004) during the compression test of apricot pit and by Altuntas and Yildiz (2007) studying the mechanical properties of faba bean. No equation was found to describe adequately the deformation in rupture when the moisture content of rough rice was reduced.

The mean maximum compression force values of rough and dehulled rice grains as a function of moisture content (d.b.) at a deformation of 0.001 $\mathrm{m}$ are shown in Figure 5. The compression force necessary for deforming the rough rice was signif- icantly higher than for dehulled rice, at all analyzed moisture contents, according to the Tukey's test at $5 \%$ probability. The rice hull presents a rigid structure protecting the endosperm of the grain thus requiring more force to deform the grain. The mean compression force required to deform $0.001 \mathrm{~m}$ of the product, at different moisture contents, varied from 131 to $171 \mathrm{~N}$ for dehulled rice and 203 to $283 \mathrm{~N}$ for rough rice. When moisture content was decreased, the compression force values varied randomly, independent of processing type. This contradicts results obtained by several researchers who reported the maximum compression force to increase in proportion to a decrease in moisture content (Henry et al., 2000; Ribeiro, Corrêa, Goneli, \& Rodrigues, 2005; Gupta \& Das, 2000).

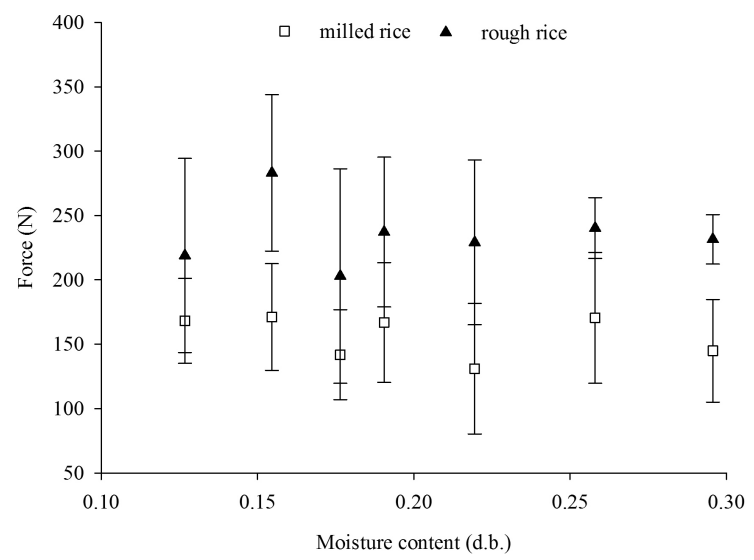

Figure 5: Rough and milled rice maximum compression force $(\mathrm{N})$ mean values as a function of moisture content (d.b.) for a $0.001 \mathrm{~m}$ deformation. Mean values followed by the same letter for the same moisture content did not differ according to the Tukey's test at $5 \%$ probability.

The proportional deformity modulus, which was derived from the compression force data, showed the same behavior as the compression force, as a function of moisture content.

The mean proportional deformity modulus values of rough and dehulled rice, as a function of moisture content (d.b.), at a fixed deformation of $0.001 \mathrm{~m}$ are shown in Figure 6. The high value of deformity modulus means that a higher force should be applied in order to obtain a spe- 
$164 \mid$ Resende et al.

cific deformation (Batista et al., 2003). The proportional deformity modulus values of rough rice were significantly higher than for dehulled rice according to the Tukey's test at $5 \%$ probability for all moisture contents. In the range of moisture content used in this work it was observed that the magnitude of proportional deformity modulus of rough and dehulled rice frequently oscillated, indicating no clear tendency as a function of moisture content.

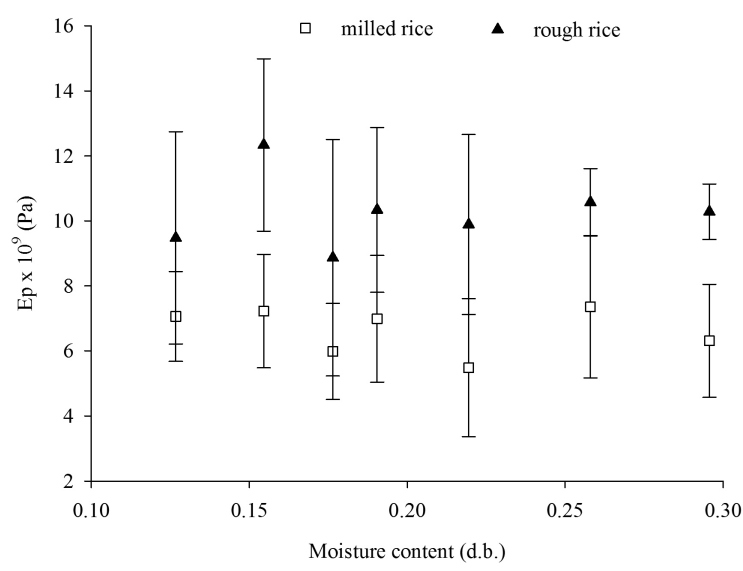

Figure 6: Mean values of the proportional deformity modulus (Ep x $\left.10^{9} \mathrm{~Pa}\right)$ for rough and milled rice as a function of moisture content (d.b.) for a $0.001 \mathrm{~m}$ deformation. Mean values followed by the same letter for the same moisture content did not differ according to the Tukey's test at $5 \%$ probability.

The proportional deformity modulus values varied from $5.5 \times 10^{9}$ to $7.4 \times 10^{9} \mathrm{~Pa}$ for dehulled rice and from 9.5 to $12.3 \times 10^{9} \mathrm{~Pa}$ for rough rice. These values are slightly superior to those observed by Ribeiro et al. (2005) who obtained proportional deformity modulus values between $2.31 \times 10^{8}$ and $1.1 \times 10^{8} \mathrm{~Pa}$ for compression at the natural rest position, for a moisture content range of 0.58 to 0.10 (d.b.) and deformation of $0.002 \mathrm{~m}$, using soybeans. Also, Resende (2006) described values between $6.7 \times 10^{7}$ and $3.4 \times 10^{8}$ $\mathrm{Pa}$, for proportional deformity modulus of edible bean grains compressed at their natural rest position, for a moisture content between 0.42 and 0.13 (d.b.) and a fixed deformation of 0.0012 $\mathrm{m}$. Couto et al. (2002) reported that the propor- tional deformity modulus of coffee with moisture content of approximately 2.5 (d.b.), compression velocity of $1.7 \times 10^{-4} \mathrm{~m} \mathrm{~s}^{-1}$ and in the deformation range of 1 to $6 \times 10^{-1} \mathrm{~m}$ presented values of $1.0 \times 10^{7}$ to $3.0 \times 10^{7} \mathrm{~Pa}$ for coffee cherry fruit and $7.0 \times 10^{7}$ to $1.5 \times 10^{8} \mathrm{~Pa}$ for green coffee fruit. Batista et al. (2003) subsequently reported proportional deformity modulus values of coffee fruits, in the moisture content range of 1.50 to 0.14 (d.b.), for the three ripening stages, subject to drying air temperatures of 50,55 and $60{ }^{\circ} \mathrm{C}$, between $2.0 \times 10^{7}$ and $1.8 \times 10^{8} \mathrm{~Pa}$ for coffee cherry fruits, $5.0 \times 10^{7}$ to $4.0 \times 10^{8} \mathrm{~Pa}$ for green fruits and $1.0 \times 10^{7} \times 10^{9}$ to $5.0 \times 10^{8} \mathrm{~Pa}$ for greenish fruits.

\section{Conclusions}

A reduction in moisture content increased the mean rupture forces from 37.2 to $70.6 \mathrm{~N}$ for dehulled rice and from 48.0 to $79.5 \mathrm{~N}$ for rough rice. The mean compression force required to deform the product by $0.001 \mathrm{~m}$, in the studied 0.12 to 0.30 (d.b) moisture content range, varied from 131 to $171 \mathrm{~N}$ for dehulled rice and 203 to $283 \mathrm{~N}$ for rough rice. The mean proportional deformity modulus values varied from $5.5 \times 10^{9}$ to $7.4 \times 10^{9}$ Pa for dehulled rice and $9.5 \times 10^{9}$ to $12.3 \times 10^{9} \mathrm{~Pa}$ for rough rice during the compression test at the natural rest position for a deformation of $0.001 \mathrm{~m}$ and moisture content ranging from 0.30 to 0.12 (d.b.). Rough rice presented higher resistance to compression than dehulled rice.

\section{Acknowledgements}

The authors express their gratitude to CAPES, $\mathrm{CNPq}$ and FAPEMIG for the financial support to perform this work.

\section{References}

Altuntas, E., \& Yildiz, M. (2007). Effect of moisture content on some physical and mechanical properties of faba bean (Vicia faba L.) grains. Journal of Food Engineering, 78(1), 174-183. doi:10.1016/j.jfoodeng.2005.09. 013 
ASAE. (1974). Autoridade de segurança alimentar e económica. agricultural engineers yearbook of standards. St. Joseph, Michigan: American Society of Agricultural Engineers.

Bargale, P., Irudayaraj, J., \& Marquis, B. (1995). Studies on rheological behavior of canola and wheat. Journal of Agricultural Engineering Research, 61(4), 267-274. doi:10 . 1006/jaer.1995.1054

Batista, C. S., Couto, S. M., Cecon, P. R., \& Peixoto, A. B. (2003). Efeito da temperatura do ar de secagem, do teor de umidade e do estádio de maturação no módulo de deformidade de frutos de café (Coffea arabica L.) Revista Brasileira de Armazenamento, $6,42-53$.

Corrêa, P. C., da Silva, F. S., Jaren, C., Afonso Junior, P. C., \& Arana, I. (2007). Physical and mechanical properties in rice processing. Journal of Food Engineering, 79(1), 137-142. doi:10.1016/j.jfoodeng.2006.01. 037

Couto, S. A., Batista, A. B., C. S.and Peixoto, \& Devilla, I. A. (2002). Comportamento mecânico de frutos de café: módulo de deformidade. Revista Brasileira de Engenharia Agrícola e Ambiental, 6(2), 285-294.

Dong, R., Lu, Z., Liu, Z., Koide, S., \& Cao, W. (2010). Effect of drying and tempering on rice fissuring analysed by integrating intrakernel moisture distribution. Journal of Food Engineering, 97(2), 161-167. doi:10. 1016/j.jfoodeng.2009.10.005

Goneli, A. L. D., Correa, P. C., Resende, O., \& Reis Neto, S. A. (2007). Electrical conductivity for quality evaluation of popcorn kernels subjected to mechanical damage. Biosystems Engineering, 96(3), 361-367. doi:10.1016/j.biosystemseng.2006.10.009

Guha, M., \& Ali, S. Z. (2006). Extrusion cooking of rice: effect of amylose content and barrel temperature on product profile. Journal of Food Processing And Preservation, 30(6), 706-716. doi:10.1111/j.1745-4549.2006. 00099.x

Gupta, R., \& Das, S. (2000). Fracture resistance of sunflower seed and kernel to compressive loading. Journal of Food Engineering,
46(1), 1-8. doi:10.1016 / S0260-8774(00) 00061-3

Gustafson, R., \& Hall, G. (1972). Density and porosity changes of shelled corn during drying. Transactions of the ASAE, 15(3), 523$\&$.

Henry, Z., Su, B., \& Zhang, H. (2000). Resistance of soya beans to compression. Journal of Agricultural Engineering Research, 76(2), 175-181. doi:10.1006/jaer.2000.0546

Kunze, O. R., \& Choudhury, M. S. U. (1972). Moisture adsorption related to the tensile strength of rice. Cereal Chemistry, $49(6)$, 684-696.

Laskowski, J, \& Lysiak, G. (1999). Use of compression behaviour of legume seeds in view of impact grinding prediction. Powder Technology, 105(1-3), 83-88. 9th European Symposium on Comminution and Classification, ALBI, FRANCE, SEP 08-10, 1998. doi:10.1016/S0032-5910(99)00121-7

Li, Y, Zhang, Q, Puri, V., \& Manbeck, H. (1989). Physical properties effect on stress-strain behavior of wheat en masse.1. load response dependence on initial bulk density in moisture content. Transactions of the ASAE, 32(1), 194-202.

Liu, M, Haghighi, K, Stroshine, R., \& Ting, E. (1990). Mechanical-properties of the soybean cotyledon and failure strength of soybean kernels. Transactions of the ASAE, $33(2), 559-566$.

Mohsenin, N. N. (1986). Physical properties of plant and animal materials. New York: Gordon and Breach Publishers.

Oliveros-Tascón, C. E., Montoya-Restrepo, E. C., \& Ayala, A. A. (2002). Efecto de la broca del café em la firmeza del grano em los estados de cereja, pergamino húmedo y pergamino seco. Cenicafe, 53(1), 25-33.

Prussia, S. E., \& Campbell, D. T. (1985). Apparent modulus elasticity of maturing pecans. Transactions of the ASAE, 28(4), 12901296.

Resende, O. (2006). Variação das propriedades físicas e mecânicas e da qualidade do feijão (Phaseolus vulgaris L.) durante a secagem e o armazenamento (doctoral dissertation). (Doctoral dissertation, Available from Universidade Federal de Viçosa). 
Ribeiro, D. M., Corrêa, P. C., Goneli, A. L. D., \& Rodrigues, D. H. (2005). Propriedades mecânicas dos grãos de soja em função do teor de água. In In sbea (eds). anais do congresso brasileiro de engenharia agrícola. paper presented at xxxiv congresso brasileiro de engenharia agrícola, held at universidade luterana do brasil, canoas, 2629 (pp. 1-4). Canoas: SBEA.

Vursavus, K, \& Ozguven, F. (2004). Mechanical behaviour of apricot pit under compression loading. Journal of Food Engineering, 65(2), 255-261. doi:10.1016/j. jfoodeng. 2004.01.022

White, G. M., Ross, I. J., \& Poneleit, C. G. (1982). Stress crack development in popcorn as influenced by drying and rehydration processes. Transactions of the ASAE, $25(3), 768-772$.

Zhang, Q, Li, Y, Puri, V., \& Manbeck, H. (1989). Physical properties effect on stress-strain behavior of wheat en masse.2. constitutive elastoplastic parameter dependence on initial bulk density and moisture content. Transactions of the ASAE, 32(1), 203-209. 